\title{
Phylogenetic and genetic variation among Fe(II)- oxidizing acidithiobacilli supports the view that these comprise multiple species with different ferrous iron oxidation pathways
}

Correspondence

Violaine Bonnefoy

bonnefoy@ifr88.cnrs-mrs.fr

Received 11 August 2010

Revised 21 September 2010

Accepted 26 September 2010

\author{
Agnès Amouric, ${ }^{1}$ Céline Brochier-Armanet, ${ }^{1}$ D. Barrie Johnson, ${ }^{2}$ \\ Violaine Bonnefoy ${ }^{1} \dagger$ and Kevin B. Hallberg ${ }^{2} \dagger$ \\ ${ }^{1}$ Laboratoire de Chimie Bactérienne, UPR-CNRS 9043, Institut de Microbiologie de la \\ Méditerranée, Aix-Marseille Université, 31 chemin Joseph Aiguier, 13009, Marseille, France \\ ${ }^{2}$ School of Biological Sciences, College of Natural Sciences, Bangor University, Bangor LL57 2UW, \\ UK
}

\begin{abstract}
Autotrophic acidophilic iron- and sulfur-oxidizing bacteria of the genus Acidithiobacillus constitute a heterogeneous taxon encompassing a high degree of diversity at the phylogenetic and genetic levels, though currently only two species are recognized (Acidithiobacillus ferrooxidans and Acidithiobacillus ferrivorans). One of the major functional disparities concerns the biochemical mechanisms of iron and sulfur oxidation, with discrepancies reported in the literature concerning the genes and proteins involved in these processes. These include two types of high-potential iron-sulfur proteins (HiPIPs): (i) Iro, which has been described as the iron oxidase; and (ii) Hip, which has been proposed to be involved in the electron transfer between sulfur compounds and oxygen. In addition, two rusticyanins have been described: (i) rusticyanin $A$, encoded by the rus $A$ gene and belonging to the well-characterized rus operon, which plays a central role in the iron respiratory chain; and (ii) rusticyanin $B$, a protein to which no function has yet been ascribed. Data from a multilocus sequence analysis of 21 strains of Fe(II)-oxidizing acidithiobacilli obtained from public and private collections using five phylogenetic markers showed that these strains could be divided into four monophyletic groups. These divisions correlated not only with levels of genomic DNA hybridization and phenotypic differences among the strains, but also with the types of rusticyanin and HiPIPs that they harbour. Taken together, the data indicate that $\mathrm{Fe}(\mathrm{II})$-oxidizing acidithiobacilli comprise at least four distinct taxa, all of which are able to oxidize both ferrous iron and sulfur, and suggest that different iron oxidation pathways have evolved in these closely related bacteria.
\end{abstract}

\section{INTRODUCTION}

The majority of obligately chemolithoautotrophic acidophilic bacteria that can oxidize ferrous iron [Fe(II)], sulfur

†These authors contributed equally to this work/paper.

Abbreviations: BV, bootstrap value; HiPIP, high potential iron-sulfur protein; MLSA, multilocus sequence analysis; PP, posterior probability; RISC, reduced inorganic sulfur compound.

The GenBank/EMBL/DDBJ accession numbers for the sequences reported in this paper are provided in Figs 2-4 and Supplementary Table S2.

A supplementary figure, showing determination of the presence or absence of rus $A$ and rus $B$ in Fe(II)-oxidizing acidithiobacilli that reportedly contain both genes, and two supplementary tables, listing oligonucleotides used and database accession numbers of the nucleotide sequences analysed, with supplementary references, are available with the online version of this paper. and reduced inorganic sulfur compounds (RISCs) have for many years been considered a priori to be strains of the well-documented species Acidithiobacillus ferrooxidans (At. ferrooxidans). The genus Acidithiobacillus has generally been considered to be a member of the Gammaproteobacteria, though recent phylogenetic analysis suggests it arose after divergence from the Alphaproteobacteria but before the Betaproteobacteria/Gammaproteobacteria split (Williams et al., 2010). There have been numerous reports suggesting that $\mathrm{Fe}(\mathrm{II})$-oxidizing acidithiobacilli are a heterogeneous collection of bacteria with sufficient genetic variability to warrant classification as more than one species (Harrison, 1982, 1984; Novo et al., 1996; Amils et al., 1998; Selenska-Pobell et al., 1998; Paulino et al., 2001; Karavaiko et al., 2003; Mitchell et al., 2003; Bergamo et al., 2004; Akbar et al., 2005; Waltenbury et al., 2005; Peng et al., 2006; Ni et al., 2007, 2008a, b). For instance, a 
recent study using microarrays of the whole genome of the At. ferrooxidans type strain (ATCC 23270) showed that 12 strains isolated from different locations, and presumptively identified as At. ferrooxidans, were highly diverse at the genomic level (Luo et al., 2009). In addition to genetic variability, several phenotypic differences have been observed among $\mathrm{Fe}$ (II)-oxidizing acidithiobacilli, such as their motility and the presence/absence of flagella (Dispirito et al., 1982; Valdés et al., 2008; Hallberg et al., 2009, 2010; Li et al., 2010), as well as their optimal pH and temperature for growth (Harrison, 1982; Kupka et al., 2007; Dave et al., 2008; Ni et al., 2008b; Hallberg et al., 2009, 2010). On the basis of several of these differentiating characteristics, a new species (Acidithiobacillus ferrivorans; At. ferrivorans) has recently been proposed to circumscribe some of the $\mathrm{Fe}(\mathrm{II})$-oxidizing acidithiobacilli (Hallberg et al., 2009, 2010).

One of the major functional disparities among the Fe(II)oxidizing acidithiobacilli concerns their propensities and mechanisms for oxidation of $\mathrm{Fe}(\mathrm{II})$ and RISCs. Different strains have been reported to display very different specific rates of $\mathrm{Fe}(\mathrm{II})$ oxidation (e.g. Suzuki et al. 1990). Harvested biomass of some strains is able to oxidize $\mathrm{Fe}(\mathrm{II})$ immediately, irrespective of the substrate on which they have been grown, while others only do so when grown on $\mathrm{Fe}(\mathrm{II})$ (Suzuki et al., 1990), suggesting either constitutive or inducible expression of the genes involved. Differences concerning RISC oxidation have also been observed, including (i) low RISC-oxidizing activities of some strains compared with others (Wakao et al., 1991; Ni et al., 2008b; Hallberg et al., 2010) and (ii) the absence in at least one strain of the thiosulfate ubiquinone oxidoreductase that is found in the type strain (Wakai et al., 2004). Furthermore, some strains oxidize $\mathrm{Fe}(\mathrm{II})$ and sulfur simultaneously, while others oxidize $\mathrm{Fe}(\mathrm{II})$ prior to sulfur (Suzuki et al., 1990; Yarzábal et al., 2004).

In addition to these observations, inconsistencies have been reported in the literature regarding the genes encoding redox proteins involved in $\mathrm{Fe}(\mathrm{II})$ and RISC oxidation pathways. For instance, the unique high-potential ironsulfur protein (HiPIP) present in At. ferrooxidans has been proposed to be involved in the sulfur oxidation respiratory chain in a number of strains, including the type strain and ATCC 33020 (Bruscella et al., 2005, 2007; Quatrini et al., 2006, 2009; Valdés et al., 2008), while it was described as the first electron acceptor from $\mathrm{Fe}(\mathrm{II})$ in some other strains (e.g. JCM 7811) (Fukumori et al., 1988; Kusano et al., 1992; Cavazza et al., 1995) (Fig. 1a). The HiPIP has been referred to as Hip in the former case, and Iro (iron-oxidizing enzyme) in the latter. Also, several strains presumptively identified as At. ferrooxidans have been reported to have two distinct types of the blue copper protein rusticyanin (Sasaki et al., 2003). The first (RusA) was detected in some At. ferrooxidans strains including the type strain and ATCC 33020 (see references in Holmes \& Bonnefoy, 2007), whereas the second (RusB) was found in some other strains (e.g. JCM 3865, JCM 7811 and IFO 14246) (Sasaki et al.,
2003) and recently in most strains of At. ferrivorans (Hallberg et al., 2009, 2010). While most strains carry only one type of rusticyanin gene, some strains have been reported to possess both (JCM 7811, JCM 3865 and IFO 14246) (Sasaki et al., 2003). The rusA gene belongs to the rus operon, which encodes two cytochromes $c$ and the $a a_{3}$ cytochrome oxidase (Fig. 1b), all of which have been shown to be involved in $\mathrm{Fe}(\mathrm{II})$ oxidation (see references in Holmes \& Bonnefoy, 2007; Quatrini et al., 2009). While RusA is considered to play a central role in this process, the function of RusB, which has a lower kinetic rate constant for electron transfer from $\mathrm{Fe}(\mathrm{II})$ (Ida et al., 2003), has not been established. Interestingly, neither rus nor rusticyanin has been detected in one strain (CF27) of At. ferrivorans, though this strain is capable of growth with $\mathrm{Fe}(\mathrm{II})$ as electron donor (Blake \& Johnson, 2000; Hallberg et al., 2009, 2010). In addition, strain AF2, presumptively identified as At. ferrooxidans, contains neither the rusA nor the $\operatorname{coxC}$ ( $a a_{3}$-type cytochrome oxidase subunit III) genes from the rus operon (Chen et al., 2009). This suggests that both of these strains use a different $\mathrm{Fe}(\mathrm{II})$ respiratory chain from that of At. ferrooxidans ATCC $23270^{\mathrm{T}}$.

All of these observations support the hypothesis that the $\mathrm{Fe}(\mathrm{II})$-oxidizing acidithiobacilli encompass distinct species, including At. ferrooxidans and At. ferrivorans, that are metabolically similar but taxonomically distinct. In this paper, we address two questions. (i) Is there a correlation between phylogenetic relationships and genetic heterogeneity among the $\mathrm{Fe}(\mathrm{II})$-oxidizing acidithiobacilli, in particular concerning rusA/B, hip/iro genes? (ii) Could such heterogeneity be useful in delineating different species of these bacteria? To answer these questions we have reconstructed the phylogeny of $21 \mathrm{Fe}(\mathrm{II})$-oxidizing acidithiobacilli based on a multilocus sequence analysis (MLSA), and investigated the presence of genes encoding the two rusticyanins $(r u s A / B)$ and the two HiPIPs (hip/iro).

\section{METHODS}

Strain selection and cultivation conditions. The $\mathrm{Fe}$ (II)-oxidizing acidithiobacilli used in this study are listed in Table 1, of which the genome sequences of two (ATCC $23270^{\mathrm{T}}$ and ATCC 53993) are in the public domain. Strains CC1, CB5 and B20 were isolated from arsenicrich mining sites, while strains $\mathrm{R} 1, \mathrm{~A} 1$ and $\mathrm{A} 2$ have been described as producing more extracellular polysaccharide (EPS) than At. ferrooxidans ATCC $23270^{\mathrm{T}}$ (Harneit et al., 2006).

Purity of cultures was tested by streaking onto both ferrous sulfate and yeast extract overlay solid media (Johnson \& Hallberg, 2007) to screen for the presence of single-colony morphologies of $\mathrm{Fe}(\mathrm{II})$ oxidizing bacteria and heterotrophic contaminants, respectively. Following the inference that JCM 7811 comprises more than one strain of $\mathrm{Fe}(\mathrm{II})$-oxidizing acidophile, the freeze-dried biomass obtained was suspended in $200 \mu$ l acidified ( $\mathrm{pH} 2.5)$ basal salts solution and portions were inoculated into a $20 \mathrm{mM}$ ferrous sulfate/ basal salts/trace elements medium (Wakeman et al., 2008) that had been adjusted to either $\mathrm{pH} 1.6$ or 2.2. When the cultures had oxidized most of the ferrous iron (as indicated by a colour change from colourless to orange), they were streak-inoculated onto ferrous iron overlay plates, and representative colonies of differing morphologies 
(a)
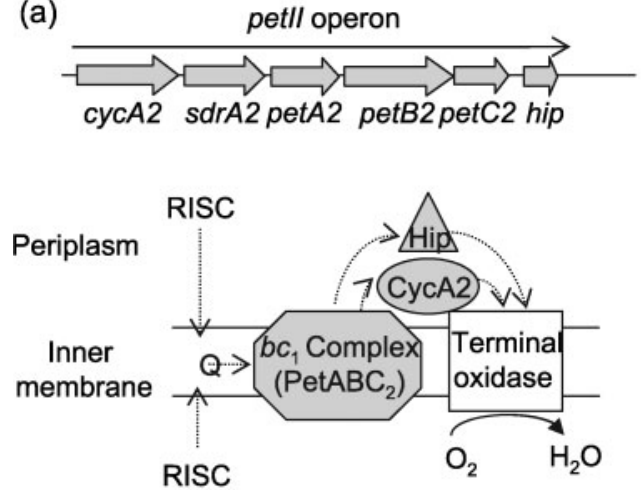

(b)
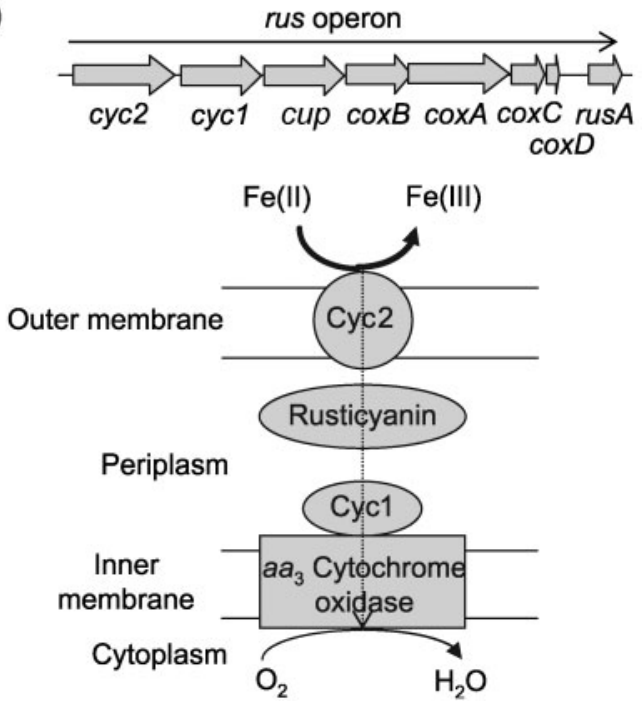
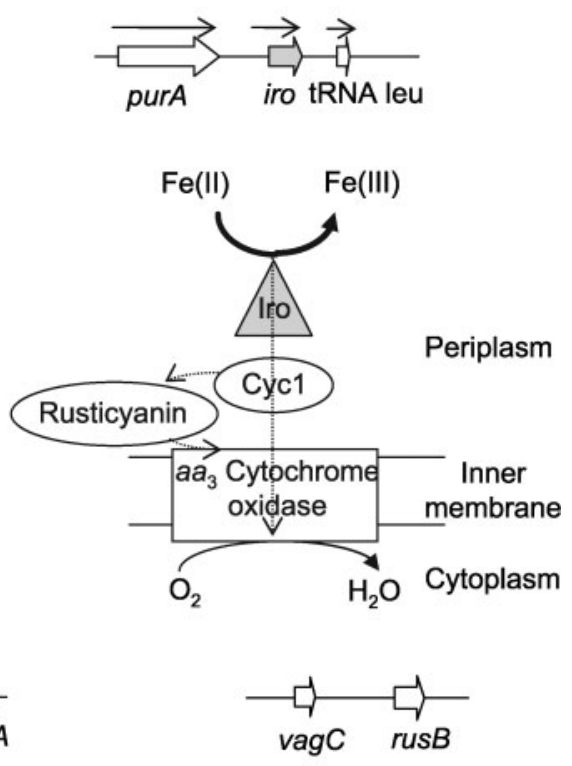

?

Fig. 1. Genetic organization of the rusticyanin- and HiPIP-encoding genes and the pathways in which they are involved. (a) hip in At. ferrooxidans ATCC $23270^{\top}$ and ATCC 33020 involved in the electron transfer chain between RISCs and $\mathrm{O}_{2}$; iro in JCM 7811 proposed to be involved in the electron transfer chain between $\mathrm{Fe}(\mathrm{II})$ and $\mathrm{O}_{2}$. (b) rusA in At. ferrooxidans ATCC $23270^{\top}$ and ATCC 33020 involved in the Fe(II) oxidation pathway; rusB in JCM 3865, JCM 7811 and IFO 14246, for which a role is unknown. Solid arrows represent transcriptional units; dotted arrows represent electron transport.

were picked off and maintained as separate cultures (denoted as JCM 7811-P1 and JCM 7811-P4).

Most of the strains were grown under aerobic conditions at $30{ }^{\circ} \mathrm{C}$ in acidified ( $\mathrm{pH}$ 1.6) ferrous sulfate/basal salts liquid medium, as described previously (Yarzábal et al., 2003). Strains of At. ferrivorans (which is less acidophilic than At. ferrooxidans) were also grown at $30{ }^{\circ} \mathrm{C}$ but at $\mathrm{pH} 2.2$ (Hallberg et al., 2010).

DNA extraction, amplification and sequencing. Genomic DNA from most of the Acidithiobacillus strains was prepared with the NucleoSpin Tissue kit (Macherey Nagel). At. ferrivorans cells and those from the original JCM and IFO strain suspensions $(100 \mu \mathrm{l})$ or from liquid cultures of the latter $(1 \mathrm{ml})$ were harvested, and crude DNA was extracted as described previously (Okibe et al., 2003).

Primers used for PCR amplification of each targeted gene and the sizes of the expected PCR products are described in Supplementary Table S1 available with the online version of this paper. The PCR program consisted of an initial denaturation step at $94{ }^{\circ} \mathrm{C}$ for 2 min $30 \mathrm{~s}$, followed by 30 (or 40) cycles of $30 \mathrm{~s}$ at $94^{\circ} \mathrm{C}, 30-60 \mathrm{~s}$ at primer annealing temperature (see Supplementary Table S1), 30-90 s at $72{ }^{\circ} \mathrm{C}$, with a final extension step at $72{ }^{\circ} \mathrm{C}$ for $7 \mathrm{~min}$. PCR products were analysed by electrophoresis in a $1 \%$ agarose gel, then concentrated and purified using Microcon PCR (Millipore) or QIAquick (Qiagen) reagents.

Nucleotide sequences of the amplified DNA were determined by Cogenics or Eurofins MWG operon, or as described previously (Hallberg et al., 2006).

Phylogenetic analysis. The sequences of the phylogenetic markers used in this study [rrs (16S rRNA gene), 16S-23S ITS1, atpD, nifH, recA, rus $A / B$ and iro/hip] were obtained from the published genomes of At ferrooxidans ATCC $23270^{\mathrm{T}}$ and strain ATCC 53993, or, for other strains, were determined as described above. For the analysis of the rrs gene, we used sequences from two closely related species (Acidithiobacillus thiooxidans and Acidithiobacillus albertensis) as 
Table 1. Strains of Fe(II)-oxidizing acidithiobacilli used in this study

\begin{tabular}{|c|c|c|c|}
\hline Strain $^{*}$ & Origin & $\begin{array}{l}\text { Percentage DNA:DNA } \\
\text { hybridization (against the } \\
\text { strain listed) }\end{array}$ & Source or reference \\
\hline $\begin{array}{l}\text { At. ferrooxidans } \\
{\text { ATCC } 23270^{\mathrm{T}}}^{\text {ATC }}\end{array}$ & Acid bituminous coal mine effluent, USA & $\begin{array}{l}94(\text { ATCC 19859) } \\
91(\mathrm{~A} 1) \dagger\end{array}$ & $\begin{array}{l}\text { American Type Culture Collection } \\
\text { (Leathen \& Braley, 1954) }\end{array}$ \\
\hline ATCC 53993 & $\begin{array}{l}\text { Derived from Leptospirillum ferrooxidans } \\
\text { DSM } 2705^{\mathrm{T}} \text { (ex Markosyan 1972) }\end{array}$ & & Hippe (2000) \\
\hline ATCC 19859 & Acid copper mine leaching water, Canada & $81(\mathrm{~A} 2) \dagger$ & $\begin{array}{l}\text { American Type Culture Collection } \\
\text { (Razzell \& Trusell, 1963) }\end{array}$ \\
\hline Al & Disused sulfidic ore mine, Rammelsberg, Germany & $99(\mathrm{~A} 2) \dagger$ & Brauckmann (1985) \\
\hline A2 & Disused sulfidic ore mine, Rammelsberg, Germany & & Brauckmann (1985) \\
\hline $\begin{array}{l}\text { ATCC } 33020 \\
(11 \mathrm{Fe})\end{array}$ & Uranium mine, Japan & $\begin{array}{l}63(\text { At. ferrooxidans } \\
\left.\text { ATCC } 23270^{\mathrm{T}}\right) \ddagger \\
60(\text { ATCC } 19859) \S\end{array}$ & $\begin{array}{l}\text { American Type Culture Collection } \\
\text { (Tomizuka et al., 1976) }\end{array}$ \\
\hline $\mathrm{CC} 1$ & Acid mine drainage, Carnoulès, France & & Duquesne et al. (2003) \\
\hline CB5 & Acid mine drainage, Carnoulès, France & & $\begin{array}{l}\text { O. Bruneel and others, unpublished } \\
\text { data }\end{array}$ \\
\hline B20 & Acid mine drainage, Carnoulès, France & & Egal et al. (2009) \\
\hline BRGM1 & $\begin{array}{l}\text { Isolate from BRGM consortium (sulfide } \\
\text { ore mine, South Africa) }\end{array}$ & & Liu et al. (2000) \\
\hline $\begin{array}{l}\text { At. ferrivorans } \\
\left(\text { DSM } 22755^{\mathrm{T}}\right)\end{array}$ & Copper mine spoil drainage, Norway & $\begin{array}{l}37(\text { At. ferrooxidans } \\
\left.\text { ATCC } 23270^{\mathrm{T}}\right) \|\end{array}$ & Hallberg et al. (2010) \\
\hline Peru6 & Abandoned mine drainage in the Andes, Peru & & Hallberg et al. (2010) \\
\hline OP14 & Abandoned Cae Coch pyrite mine, North Wales, UK & & Hallberg et al. (2010) \\
\hline CF27 & Abandoned copper/cobalt mine drainage, ID, USA & & Hallberg et al. (2010) \\
\hline SS3-P1 & $\begin{array}{l}\text { Clonal isolate obtained in this study from SS3 culture, } \\
\text { Norilsk mining area, Russia }\end{array}$ & & Kupka et al. (2007) \\
\hline $\begin{array}{r}\text { JCM } 3865 \\
\text { (THI135) }\end{array}$ & Acid mine water, Shimokawa, Japan & & $\begin{array}{l}\text { Japan Collection of Microorganisms } \\
\text { (Takamori et al., 1983) }\end{array}$ \\
\hline JCM 7811-P1 & $\begin{array}{l}\text { Clonal isolate obtained in this study from the JCM } 7811 \\
\text { culture originating in the Matsuo sulfur and iron sulfide } \\
\text { mine, Japan }\end{array}$ & & $\begin{array}{l}\text { Japan Collection of Microorganisms } \\
\text { (Wakao et al., 1991) }\end{array}$ \\
\hline JCM 7811-P4 & ibid & & \\
\hline JCM $7812(\mathrm{Fe} 2)$ & Matsuo sulfur and iron sulfide mine, Japan & & $\begin{array}{l}\text { Japan Collection of Microorganisms } \\
\text { (Wakao et al., 1991) }\end{array}$ \\
\hline $\begin{array}{l}\text { IFO } 14246 \\
(\mathrm{BA}-4)\end{array}$ & Settling pond, Belle Ayr coal mine, USA & $24($ ATCC 19859)§ & $\begin{array}{l}\text { NITE Biological Resource Center } \\
\text { (Harrison, 1982) }\end{array}$ \\
\hline $\mathrm{R} 1$ & Sulfidic copper-zinc ore (Ilba mine), Romania & $\begin{array}{l}40(\text { At. ferrooxidans } \\
\left.\text { ATCC } 23270^{\mathrm{T}}\right) \dagger\end{array}$ & Sand et al. (1992) \\
\hline
\end{tabular}

*Type strains are indicated in bold type.

$\dagger$ W. Sand, University of Duisberg-Essen, personal communication.

†This study.

\$Harrison (1982).

IIHallberg et al. (2009, 2010).

outgroups. These sequences were retrieved from the $n r$ database at the National Center for Biotechnology Information (NCBI) (accession numbers AJ459803 and AJ459804, respectively). For each marker, sequences were aligned using CLUSTAL w2 default parameters (Larkin et al., 2007). The resulting alignments were inspected using the MUST software (Philippe, 1993). Regions where the alignment was ambiguous were removed prior to phylogenetic analysis using MUST. The concatenation based on the alignments of atpD, nifH and $\operatorname{rec} A$ was constructed using in-house software.

For each marker, and for the concatenated sequences, phylogenetic trees were reconstructed using maximum-likelihood and Bayesian methods implemented, respectively, in TREEFINDER (Jobb et al., 2004) and MrBayes (Ronquist \& Huelsenbeck, 2003). For maximum-likelihood analyses, the evolutionary models used were selected according to the 'propose model' tool implemented in TREEFINDER. The branch robustness of the resulting trees was estimated by the non-parametric bootstrap procedure implemented in TREEFINDER using the same parameters. For Bayesian analyses we used the GTR model and a gamma distribution to account for evolutionary site rate variations (four categories and an estimated alpha-parameter). MrBayes was run with four chains for 1 million generations and trees were sampled every 100 generations. To construct the consensus tree, the first 1500 trees were discarded as 'burn-in'. 
DNA-DNA hybridization. Cells from 801 cultures of Fe(II)-grown At. ferrooxidans ATCC $23270^{\mathrm{T}}$ and strain ATCC 33020 were lysed using a French pressure cell (Thermo Spectronic), and genomic DNA from these lysates was purified by chromatography on hydroxyapatite, as described by Cashion et al. (1977). DNA-DNA hybridization was carried out by the Deutsche Sammlung von Mikroorganismen und Zellkulturen, as described by De Ley et al. (1970) with the modifications of Huß et al. (1983), using a Cary 100 Bio UV/Vis spectrophotometer equipped with a Peltier-thermostatted $6 \times 6$ multicell changer and a temperature controller with an in situ temperature probe (Varian).

\section{RESULTS}

\section{MLSA-based phylogeny}

While the rrs gene sequences of the strains examined showed less than $2 \%$ divergence, which is less than the often-cited threshold of $3 \%$ recommended to differentiate species (Stackebrandt \& Goebel, 1994), phylogenetic analysis clearly placed them into four distinct clusters (I, II, III and IV, Fig. 2a). Group I is represented by At. ferrooxidans ATCC $23270^{\mathrm{T}}$ and also includes ATCC 53993, ATCC 19859 and strains A1 and A2. Group II is represented by ATCC 33020, and also includes strains CC1, CB5, B20 and BRGM1. Group III is composed exclusively of strains of At. ferrivorans, and Group IV of strains JCM 7812, JCM 3865, IFO 14246 and R1. However, while these four clusters were well supported by high bootstrap values (BVs) $(\geqslant 96 \%)$ and posterior probabilities (PPs) $(\geqslant 0.98)$, the relationships to each other are not fully resolved. Indeed, while the link between Groups III and IV was well supported (BV $=96 \%$ and $\mathrm{PP}=1.0$ ), their relationship with Group II strains was less clear (BV $=78 \%$ and $\mathrm{PP}=0.74$, Fig. 2a). This lack of resolution is likely to be linked to the high similarity between rrs gene sequences, which also confounds the classification of the $\mathrm{Fe}(\mathrm{II})$ oxidizing acidithiobacilli strains based on this gene sequence alone.

Four additional markers were analysed to refine the phylogeny of $\mathrm{Fe}(\mathrm{II})$-oxidizing acidithiobacilli. Importantly, these markers are located in different regions of the chromosome, at least in those of At. ferrooxidans ATCC $23270^{\mathrm{T}}$ and strain ATCC 53993, limiting biases due to single horizontal gene transfer (HGT) of adjacent loci. The unrooted phylogenies based on each of these genes were congruent with the tree based on rrs gene sequences. In particular, Groups I to IV were recovered and well supported in all trees (Figs $2 \mathrm{~b}$ and $3 \mathrm{a}-\mathrm{c}$ ). The only exceptions were Group I and Group IV, in ITS1 and nifH trees, respectively. In the former case, ITS1 sequences from strains A1 and A2 did not cluster with other Group I sequences (Fig. 2b), while in the latter case, the JCM 3865 nifH sequence emerged as a sister of Group I, albeit with moderate statistical support $(\mathrm{BV}=82 \%$ and $\mathrm{PP}=0.69$, Fig. $3 \mathrm{~b})$. Interestingly, in the ITS1 tree, the grouping of the strains correlated with sequence lengths, as observed by $\mathrm{Ni}$ et al. (2007, 2008a). The size of the ITS1 was 441, 454, 442-443 and $452 \mathrm{bp}$ for strains from Groups I-IV, respectively. Exceptions were strains A1 and A2, which harboured an atypical and divergent ITS1 resulting from the insertions of short runs of nucleotides, which also might skew the phylogenetic analysis, and resulted in the separa- (a)

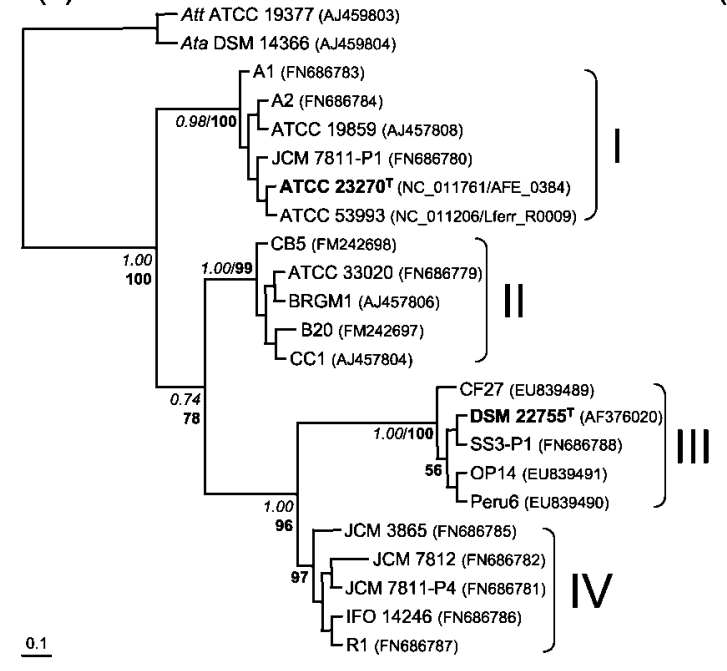

(b)

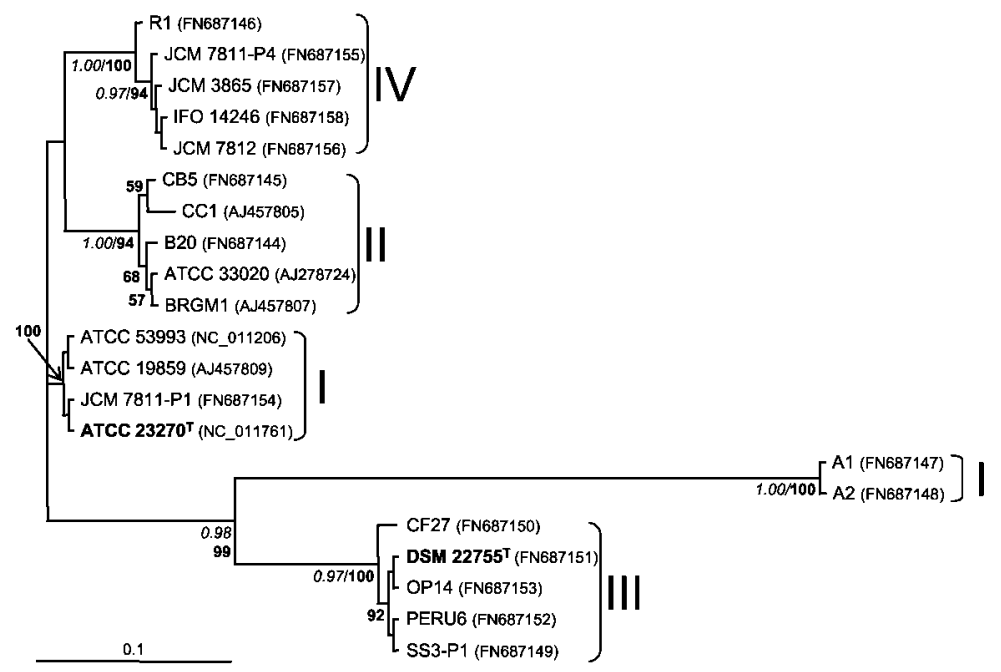

Fig. 2. Bayesian phylogenetic trees of the Fe(II)-oxidizing Acidithiobacillus rrs gene (a) and the 16S-23S rRNA ITS1 (b) (1387 and 577 positions, respectively). The rrs tree is rooted with sequences from Acidithiobacillus thiooxidans (Att) and Acidithiobacillus albertensis (Ata). The ITS1 tree is unrooted. Italicized numbers at nodes represent PPs, whereas numbers in bold type represent BVs. For clarity, only PPs greater than 0.5 and BVs greater than $50 \%$ are shown. The scale bars represent the average number of substitutions per site. At. ferrooxidans ATCC $23270^{\top}$ and At. ferrivorans DSM $22755^{\top}$ are in Group I and Group III, respectively. Accession numbers of the nucleotide sequences are given in parentheses. Type strains are indicated in bold type. 

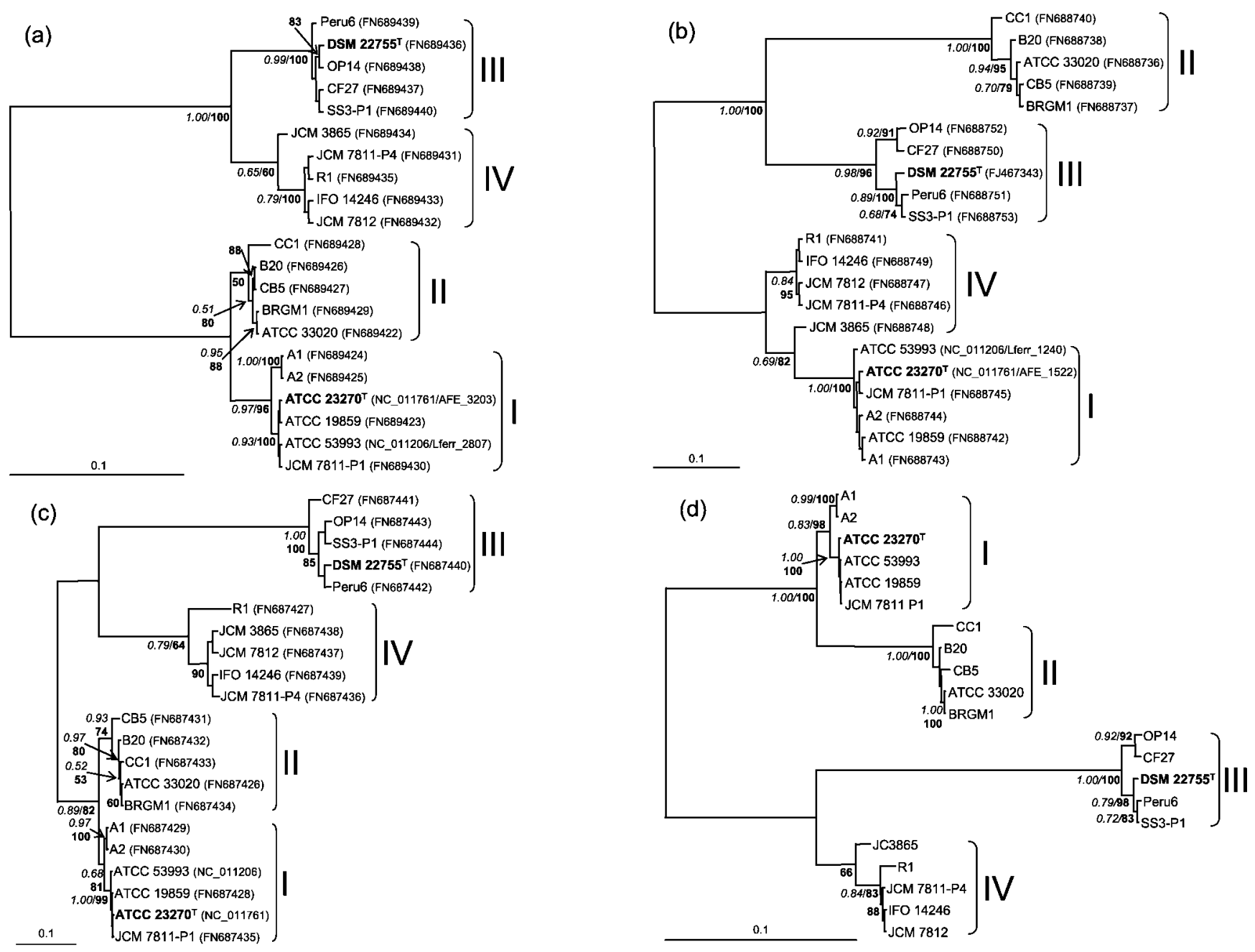

Fig. 3. Bayesian unrooted phylogenetic trees of Fe(II)-oxidizing Acidithiobacillus atpD (a) (1256 positions), nifH (b) (346 positions) and $\operatorname{rec} A$ (c) (805 positions) genes and of their concatenation (d) (2407 positions). Italicized numbers at nodes represent PPs, whereas numbers in bold type represent BVs. For clarity, only PPs greater than 0.5 and BVs greater than $50 \%$

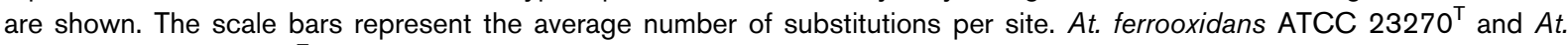
ferrivorans DSM $22755^{\top}$ are in Group I and Group III, respectively. Accession numbers of the nucleotide sequences are given in parentheses. Type strains are indicated in bold type.

tion of these two strains from the rest of the Group I strains with a very long branch (Fig. 2b). The close relationship between Group III and Group IV based on rrs analysis was also observed in the atpD and $r e c A$ trees (BV= 100 and $82 \%$, and $\mathrm{PP}=1.0$ and 0.89 ) (Fig. 3a, c).

These results support the hypothesis that $\mathrm{Fe}(\mathrm{II})$-oxidizing acidithiobacilli comprise at least four distinct taxa. However, as with the rrs gene phylogeny, the branching pattern within each group was poorly supported (most BVs $<90 \%$, Figs 2 and 3), indicating that the phylogenetic signal carried by these individual markers is not sufficient to resolve the relationships between the corresponding strains, possibly due in part to their relatively small size but also to the great similarity between sequences.
To improve the resolution of the relationships within each group, sequences of the recA, atpD and nifH genes were concatenated, leading to a supermatrix of $2407 \mathrm{nt}$ positions. The resulting phylogenetic tree supported the split of the $\mathrm{Fe}(\mathrm{II})$-oxidizing acidithiobacilli into four clades (BV $\geqslant 98 \%$ for groups I, II and III and $66 \%$ for group IV, Fig. $3 \mathrm{~d})$. Interestingly, whereas most strain relationships within groups remained poorly resolved, some well-supported groupings emerged: A1 and A2 strains within Group I $(\mathrm{BV}=100 \%$ and $\mathrm{PP}=0.99)$; the four remaining strains of Group I $(\mathrm{BV}=100 \%$ and $\mathrm{PP}=1.0)$; BRGM1 and ATCC 33020 strains within Group II $(\mathrm{BV}=100 \%$ and $\mathrm{PP}=1.0)$; OP14 and CF27 strains in Group III $(B V=92 \%$ and $\mathrm{PP}=0.92)$; Peru6 and SS3-P1 strains, together with At. ferrooxidans ATCC $23270^{\mathrm{T}}$ in Group III $(\mathrm{BV}=83 \%$ and 
$98 \%$, and $\mathrm{PP}=0.72$ and 0.79 , respectively); and IFO 14246 , JCM 7812 and JCM 7811-P4 (BV=88\%), together with R1 $(\mathrm{BV}=83 \%$ and $\mathrm{PP}=0.94)$, within Group IV.

\section{Taxonomy of Fe(II)-oxidizing acidithiobacilli}

MLSA showed that At. ferrooxidans ATCC $23270^{\mathrm{T}}$ and strain ATCC 33020 belong to two different phylogenetic groups (I and II), though their rrs genes have $99 \%$ sequence identity. The same gene of At. ferrooxidans ATCC $23270^{\mathrm{T}}$ and Group IV strain JCM 7812 shared $98.5 \%$ sequence identity. All DNA-DNA hybridization values (DDHVs) for strains identified by MLSA to be in Group I were $>80 \%$ (W. Sand, personal communication) (Table $1)$, confirming that these do indeed belong to the same species as At. ferrooxidans ATCC $23270^{\mathrm{T}}$. By contrast, Group II strain ATCC 33020 and At. ferrooxidans ATCC $23270^{\mathrm{T}}$ were shown to have a DDHV of only $63 \%$ (Table $1)$, a value similar to that $(60 \%)$ previously reported for strain ATCC 33020 and another Group I strain (ATCC 19859) (Harrison, 1982). Elsewhere, it has been found that At. ferrooxidans ATCC $23270^{\mathrm{T}}$ and Group IV strain R1 have a DDHV of $40 \%$ (W. Sand, personal communication), while Harrison (1982) had earlier reported an even smaller DDHV (24\%) for Group I strain ATCC 19859 and Group IV strain IFO 14246 (Table 1). Since DDHVs of $<70 \%$ are generally considered to indicate different species (Wayne et al., 1987), it is apparent that neither Group II nor Group IV bacteria should be regarded as strains of $A t$. ferrooxidans, like those in Group III, which are strains of At. ferrivorans.

Representative isolates from Groups I-IV revealed some phenotypic differences from each other (Table 2). These included: (i) a lesser propensity for growth on sulfur or tetrathionate (as evidenced by protracted lag phases) in strains of Groups III and IV compared with strains of Groups I and II; (ii) similar cell sizes to each other of bacteria of Groups I, II and IV, although notably smaller than that of At. ferrivorans (Group III); (iii) non-motility of cells of Groups I and IV, and motility of Groups II and III; (iv) growth at $4{ }^{\circ} \mathrm{C}$ of Group III acidithiobacilli alone; and (v) sensitivity to low $\mathrm{pH}$ and absence of growth at $\mathrm{pH} 1.6$ of Group III strains.

\section{Differences in the ferrous iron oxidation pathway among acidithiobacilli}

The biochemical mechanism by which At. ferrooxidans mediates $\mathrm{Fe}(\mathrm{II})$ oxidation has been the subject of considerable debate and some controversy for a number of years. To ascertain whether some of the disparate results reported correlate with the phylogenetic clustering of strains revealed in the present study, PCR amplification of the hip, iro, rusA and rusB genes in the strains examined was performed. The results revealed a strong correlation between the distribution of rusA/rusB and hip/iro among the strains and the four phylogenetic groups detected by MLSA (Fig. 4). Notably, the presence of a rusA gene and the absence of a rus $B$ gene were detected in strains from Groups I and II, while one, two or no copies of rusB, and no rusA gene were observed in strains from Groups III and IV with the primers used. Furthermore, whereas the hip gene was amplified from all strains in Groups I and II, only the iro gene was detected in strains from Groups III and IV with our primers. Phylogenies based on the rusA/rusB and hip/iro genes were in agreement with those obtained by MLSA (Fig. 4).

Table 2. Differentiation of Fe(II)-oxidizing Acidithiobacillus species and isolates based on selected phenotypic traits

All strains grew at 30 and $37{ }^{\circ} \mathrm{C}$ and in medium of $\mathrm{pH}$ 2.2. The main differences are indicated in bold type.

\begin{tabular}{|c|c|c|c|c|c|}
\hline Strain & MLSA group & Growth at $4{ }^{\circ} \mathrm{C}$ & Growth at $\mathrm{pH} 1.6$ & Motility & Sulfur oxidation \\
\hline JCM 7811-P1 & I & - & + & - & + \\
\hline $\mathrm{CC} 1$ & II & - & + & + & + \\
\hline At. ferrivorans DSM $22755^{\mathrm{T}} \star$ & III & + & - & + & $-1+\ddagger$ \\
\hline $\mathrm{CF} 27^{\star}$ & III & + & - & + & $-1+\ddagger$ \\
\hline JCM 7811-P4 & IV & - & + & - & $-1+\ddagger$ \\
\hline JCM 7812 & IV & - & + & - & $-1+\ddagger$ \\
\hline $\mathrm{R} 1$ & IV & - & + & - & $-1+\ddagger$ \\
\hline
\end{tabular}

${ }^{\star}$ Data from Hallberg et al. (2010).

$\dagger$ Data from Kelly \& Wood (2005).

$\ddagger$ These strains exhibited a long lag phase before growth with sulfur or tetrathionate as electron donor occurred. Upon subsequent subculturing into medium with these electron donors, lag phases were less pronounced. 

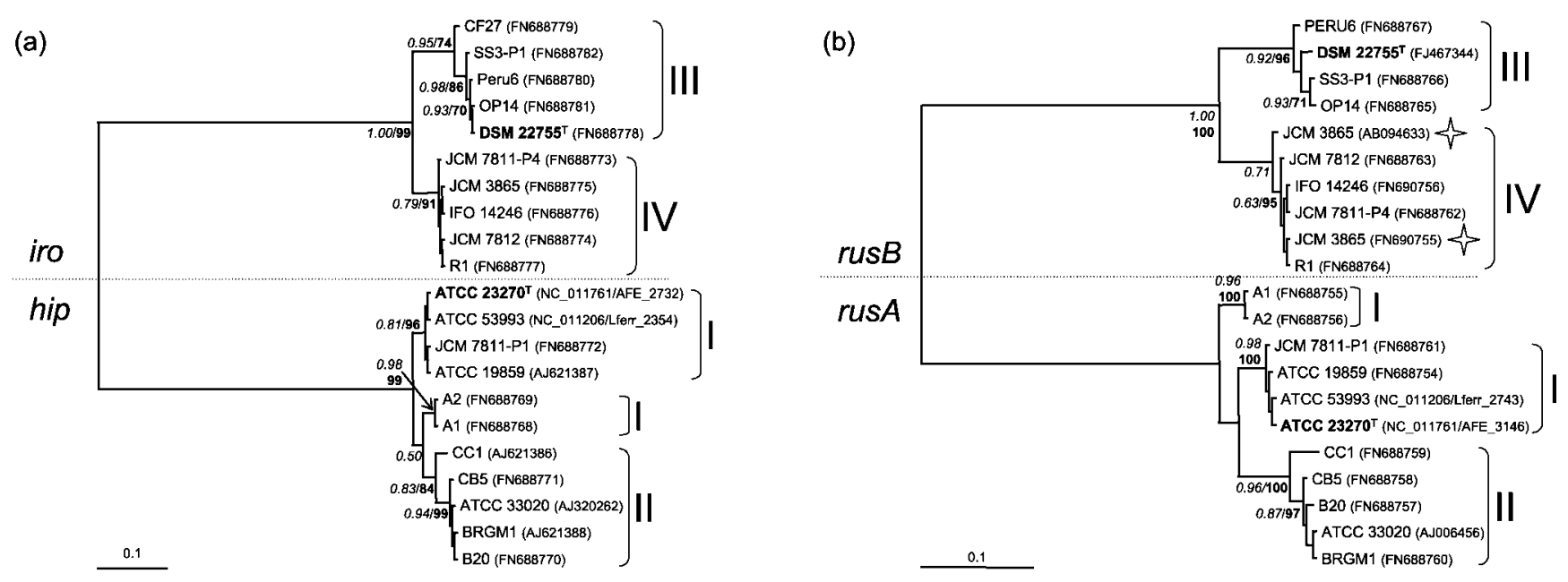

Fig. 4. Bayesian unrooted phylogenetic trees of Fe(II)-oxidizing Acidithiobacillus iro/hip (a) and rus (b) genes (358 and 392 positions, respectively). Italicized numbers at nodes represent PPs, whereas numbers in bold type represent BVs. Stars highlight the two different copies of rusB amplified from JCM 3865. For clarity, only PPs greater than 0.5 and BVs greater than $50 \%$ are shown. The scale bars represent the average number of substitutions per site. At. ferrooxidans ATCC $23270^{\top}$ and $A t$. ferrivorans DSM $22755^{\top}$ are in Group I and Group III, respectively. Accession numbers of the nucleotide sequences are given in parentheses. Type strains are indicated in bold type.

\section{Rusticyanin in strains JCM 7811, JCM 3865 and IFO 14246}

As mentioned above, some $\mathrm{Fe}(\mathrm{II})$-oxidizing acidithiobacilli reportedly have both rusA and rusB genes, and JCM 3865 has been reported to have two copies of the latter (Sasaki $e t$ al., 2003). The presence of two copies of rusB in JCM 3865 could be explained by a single and specific gene duplication event in this strain. However, since none of the confirmed pure cultures of $\mathrm{Fe}$ (II)-oxidizing acidithiobacilli analysed in this study was found to contain both rusA and rusB, we examined the possibility that the cultures previously examined might have comprised more than a single strain.

DNA extracted from the original lyophilized culture of JCM 7811 gave a strong rusA and a weak rusB PCR product, whereas DNA from subcultures grown at either $\mathrm{pH} 1.6$ or 2.2 gave relatively stronger rusB PCR products (Supplementary Fig. S1). The two colony variants obtained from the original culture, strains JCM 7811-P1 and JCM 7811-P4, matched the description of those of strains Fe1 and Fe2 (Wakao et al., 1991), which were deposited as JCM 7811 and 7812, respectively. MLSA showed that JCM 7811P1 belongs to Group I, and it was found to contain hip and rusA (but not rusB) genes (Figs 2-4). Like other Group I strains, it was not motile, grew at $\mathrm{pH} 1.6$ but not at $4{ }^{\circ} \mathrm{C}$, and oxidized RISCs efficiently (Table 2 ). In contrast, the second isolate, JCM 7811-P4 belongs to Group IV, which also includes JCM 7812. It harbours rusB (but not rusA) and iro genes (Figs 2-4). In addition, it shares physiological similarities with other representatives of Group IV; in particular, it exhibited a long lag phase prior to growth on RISCs (Table 2). It was thus apparent that the original JCM
7811 culture was mixed and contained at least two distinct strains of $\mathrm{Fe}(\mathrm{II})$-oxidizing acidithiobacilli.

In contrast, the JCM 3865 culture was confirmed to be pure. However, while it was initially described as having two copies of rusB and one of rusA, we detected only the two different rusB genes (stars in Fig. 4b) and no rusA (Supplementary Fig. S1). The same result was obtained with a few pure colonies isolated from the original culture supplied. MLSA (Figs 2-4) and physiology analysis (Table 2) placed JCM 3865 in Group IV, and like other strains in this group it also contained the iro gene (Fig. 4).

We failed to get growth from two lyophilized cultures of IFO 14246 provided independently by the National Institute of Technology and Evaluation (NITE) Biological Resource Center, Japan. However, DNA was extracted directly from one of the lyophilized cultures, and this served as template for PCR and subsequent sequencing. Each of the DNA fragments amplified was highly identical to those of JCM 3865, JCM 7812 and JCM 7811-P4. MLSA placed IFO 14246 unambiguously in Group IV (Figs 2-4). As with all strains of Group IV, rusB and iro genes were amplified from the lyophilized IFO culture, but rusA and hip were not (Supplementary Fig. S1).

\section{DISCUSSION}

DNA-DNA hybridization and phylogenetic analysis of rrs gene sequences have been the main techniques used in recent decades to determine bacterial taxonomy (Stackebrandt \& Goebel, 1994). More recently, MLSA, which has a number of advantages over more traditional 
approaches (Maiden, 2006), has been used to clarify areas where phylogenetic relationships are unclear, allowing the refinement of the taxonomy of composite bacterial groups such as the Geobacteraceae (Holmes et al., 2004), Xanthomonas (Young et al., 2008), Streptomyces (Guo et al., 2008) and Bradyrhizobium (Rivas et al., 2009). In the current work, MLSA has been used to differentiate strains of $\mathrm{Fe}(\mathrm{II})$-oxidizing acidithiobacilli and has provided firm evidence of the existence of multiple species within this bacterial group.

Collectively, the results of the $r r s$, ITS1, recA, atpD, nifH, rus $A / B$ and hip/iro phylogenetic analyses showed that the 21 strains analysed fell into four distinct groups (Figs 2-4), which currently comprise only two recognized species. Group I includes strains of At. ferroxidans while Group III is composed exclusively of At. ferrivorans strains. Group II includes ATCC 33020, a strain that has previously been suggested to be a distinct species (Selenska-Pobell et al., 1998). This grouping is similar to that of Karavaiko et al. (2003), who found that 17 strains of 'At. ferrooxidans' also fell into four distinct phylogenetic groups based on $16 \mathrm{~S}$ DNA gene sequences, though Groups III and IV are reversed in the present study. DNA-DNA hybridization data confirmed that strains of Groups II and IV, like those of At. ferrivorans (Group III), do not belong to the species At. ferrooxidans (Group I) (Table 1). Furthermore, MLSA (Figs 2-4) suggested that Groups III and IV are related and distinct from Groups I and II. Group IV strains, however, were different from Group III bacteria in some physiological traits, including growth at low temperatures, sensitivity to low $\mathrm{pH}$, cell size and motility (Table 2). We therefore suggest that phylogenetic Groups II and IV represent novel species of Acidithiobacillus, though more in-depth physiological analysis is necessary before these can be officially designated novel species.

One of the most significant findings from this work concerns the observed distribution of rusticyanin- and HiPIPencoding genes in these four groups. rus $A$ and hip genes were found only in Groups I and II, while rusB and iro were present only in Groups III and IV, which correlates with the close phylogenetic relationship between these respective groups (Figs 2-4). These data further support the view that Group II bacteria belong to a species different from those in Groups III and IV, and also that Group IV bacteria are distinct from At. ferrooxidans (Group I strains) (Figs 2-4). Also, the failure to detect any strain that harboured copies of both rusA and rusB, coupled with the finding that one of these cultures contained both Group I and Group IV strains, implies that the results of Sasaki et al. (2003) were erroneous and due to the use of mixed cultures. However, the existence of two rusB genes in strain JCM 3865 was confirmed. The differences in the distribution of rus $A / B$ and hip/iro genes suggest that pathways of ferrous iron oxidation in bacteria in Groups I and II are different from those in Groups III and IV, which probably accounts for the disparate results obtained previously by different research groups who have investigated this subject (e.g. Fukumori et al., 1988; Appia-Ayme et al.,
1999; Sasaki et al., 2003; Bruscella et al., 2005). The upstream and downstream regions of the two rusticyanin genes are also completely different. The rusA gene (in Groups I and II) belongs to the rus operon (Fig. 1b; Bengrine et al., 1998; Appia-Ayme et al., 1999; Valdés et al., 2008), which is more highly expressed when cells are grown with ferrous iron than with sulfur (Yarzábal et al., 2004; Quatrini et al., 2006, 2009). In contrast, analysis of the DNA sequence data from JCM 3865 (Sasaki et al., 2003) revealed that upstream of rusB there is a gene that encodes a putative $\mathrm{VagC}$ toxin component of a toxin-antitoxin system (Fig. 1b). The location of the rusB gene in strains of At. ferrivorans (Group III) is currently unknown, and no information is available about the regulation of the expression of this gene in any Acidithiobacillus strain. The absence of rusB (as well as rusA) in At. ferrivorans strain CF27, which nonetheless grows by iron oxidation, suggests strongly that rusticyanin is not a core component of the Fe(II)-oxidizing apparatus in Group III or (by inference) Group IV strains.

All strains in Groups III and IV have been shown to contain the iro gene, which encodes a HiPIP proposed to be an iron oxidase (Fukumori et al., 1988; Kusano et al., 1992), and which is monocistronic and located between the purA and leucyl tRNA genes (Kusano et al., 1992) (Fig. 1a). The iro gene was not detected in the genome of At. ferrooxidans ATCC $23270^{\mathrm{T}}$ and ATCC 53993 (Bruscella et al., 2005; Valdés et al., 2008; this study), and could not be amplified from any strain in Groups I and II (Bruscella et al., 2005; this study). While neither At. ferrooxidans ATCC $23270^{\mathrm{T}}$ nor Group II strain ATCC 33020 contains the iro gene, they both possess a homologue of iro, that is the hip gene. The hip gene has been shown to be located in a genetic context different from that of the iro gene, and is part of the petII operon encoding the $b c_{1}$ complex (Fig. 1a). Transcription of this gene is higher when cells are grown with sulfur than with $\mathrm{Fe}$ (II) (Quatrini et al., 2006, 2009; Bruscella et al., 2007), implying that, in contrast to iro, hip participates in the oxidation of RISCs rather than $\mathrm{Fe}(\mathrm{II})$.

The results of this study strongly suggest that at least two different pathways for $\mathrm{Fe}$ (II) oxidation have evolved in the four highly related taxa of $\mathrm{Fe}(\mathrm{II})$-oxidizing acidithiobacilli identified, and reconcile the models (Fig. 1) that had previously been considered to be conflicting. In At. ferrooxidans ATCC $23270^{\mathrm{T}}$, other Group I strains and Group II strains, proteins encoded by rusA and the corresponding operon have a central role, while in Group III (At. ferrivorans) and Group IV strains, the iron oxidase encoded by iro is probably a key component. Other questions remain, such as the role of rusB in At. ferrivorans (in those strains which possess it) and Acidithiobacillus Group IV strains, and this will be the addressed in future work.

\section{ACKNOWLEDGEMENTS}

We gratefully acknowledge M. Dopson (Linnaeus University, Sweden) for providing the SS3 culture and O. Bruneel (Montpellier University, 
France) for strains B20 and CB5. We owe special thanks to W. Sand (Duisburg-Essen University, Germany) for strains R1, A1 and A2, and for giving us access to unpublished results. We thank D. Moinier (CNRS, Marseille) for her excellent technical assistance. Part of this work was financed by the $\mathrm{EU}$ framework 6 project 'BioMinE' $\left(\mathrm{N}^{\circ} \mathrm{NM} 2 . c t, 2005.500329\right)$, and we thank our various partners on the project for their contributions to the work reported in this paper. A. A. was supported by a CNRS fellowship. D. B. J. is grateful to the Royal Society (UK) for the award of an Industrial Fellowship. C. B-A. is supported by an Action Thématique et Incitative sur Programme (ATIP) of the Centre National de la Recherche Scientifique.

\section{REFERENCES}

Akbar, T., Akhtar, K., Ghauri, M. A., Anwar, M. A., Rehman, M., Rehman, M., Zafar, Y. \& Khalib, A. M. (2005). Relationship among acidophilic bacteria from diverse environments as determined by randomly amplified polymorphic DNA analysis (RAPD). World $J$ Microbiol Biotechnol 21, 645-648.

Amils, R., Irazabal, N., Moreira, D., Abad, J. P. \& Marin, I. (1998). Genomic organization analysis of acidophilic chemolithotrophic bacteria using pulsed field gel electrophoretic techniques. Biochimie 80, 911-921.

Appia-Ayme, C., Guiliani, N., Ratouchniak, J. \& Bonnefoy, V. (1999). Characterization of an operon encoding two $c$-type cytochromes, an $a a_{3}$-type cytochrome oxidase, and rusticyanin in Thiobacillus ferrooxidans ATCC 33020. Appl Environ Microbiol 65, 4781-4787.

Bengrine, A., Guiliani, N., Appia-Ayme, C., Jedlicki, E., Holmes, D. S., Chippaux, M. \& Bonnefoy, V. (1998). Sequence and expression of the rusticyanin structural gene from Thiobacillus ferrooxidans ATCC33020 strain. Biochim Biophys Acta 1443, 99-112.

Bergamo, R. F., Novo, M. T., Verissimo, R. V., Paulino, L. C., Stoppe, N. C., Sato, M. I., Manfio, G. P., Prado, P. I., Garcia, O., Jr \& Ottoboni, L. M. (2004). Differentiation of Acidithiobacillus ferrooxidans and A. thiooxidans strains based on 16S-23S rDNA spacer polymorphism analysis. Res Microbiol 155, 559-567.

Blake, R. C. \& Johnson, D. B. (2000). Phylogenetic and biochemical diversity among acidophilic bacteria that respire on iron. In Environmental Microbe-Metal Interactions, pp. 53-78. Edited by D. R. Lovley. Washington, DC: American Society for Microbiology.

Brauckmann, B. (1985). Autotrophe und heterotrophe Bakterien im Biotop "Altes Lager Erzbergwerk Rammelsberg" und ihr Einfluss auf die Laugung sulfidischer Mischerze. $\mathrm{PhD}$ thesis, Universität Braunschweig, Braunschweig, Germany.

Bruscella, P., Cassagnaud, L., Ratouchniak, J., Brasseur, G., Lojou, E., Amils, R. \& Bonnefoy, V. (2005). The HiPIP from the acidophilic Acidithiobacillus ferrooxidans is correctly processed and translocated in Escherichia coli, in spite of the periplasm $\mathrm{pH}$ difference between these two micro-organisms. Microbiology 151, 1421-1431.

Bruscella, P., Appia-Ayme, C., Levican, G., Ratouchniak, J., Jedlicki, E., Holmes, D. S. \& Bonnefoy, V. (2007). Differential expression of two $b c_{1}$ complexes in the strict acidophilic chemolithoautotrophic bacterium Acidithiobacillus ferrooxidans suggests a model for their respective roles in iron or sulfur oxidation. Microbiology 153, 102-110.

Cashion, P., Holder-Franklin, M. A., McCully, J. \& Franklin, M. (1977). A rapid method for the base ratio determination of bacterial DNA. Anal Biochem 81, 461-466.

Cavazza, C., Guigliarelli, B., Bertrand, P. \& Bruschi, M. (1995). Biochemical and EPR characterization of a high potential iron-sulfur protein in Thiobacillus ferrooxidans. FEMS Microbiol Lett 130, 193200.
Chen, H., Yang, B. \& Chen, X. (2009). Identification and characterization of four strains of Acidithiobacillus ferrooxidans isolated from different sites in China. Microbiol Res 164, 613-623.

Dave, S. R., Gupta, K. H. \& Tipre, D. R. (2008). Characterization of arsenic resistant and arsenopyrite oxidizing Acidithiobacillus ferrooxidans from Hutti gold leachate and effluents. Bioresour Technol 99, 7514-7520.

De Ley, J., Cattoir, H. \& Reynaerts, A. (1970). The quantitative measurement of DNA hybridization from renaturation rates. Eur $J$ Biochem 12, 133-142.

Dispirito, A. A., Silver, M., Voss, L. \& Tuovinen, O. H. (1982). Flagella and pili of iron-oxidizing Thiobacilli isolated from a uranium mine in Northern Ontario, Canada. Appl Environ Microbiol 43, 1196-1200.

Duquesne, K., Lebrun, S., Casiot, C., Bruneel, O., Personne, J. C., Leblanc, M., Elbaz-Poulichet, F., Morin, G. \& Bonnefoy, V. (2003). Immobilization of arsenite and ferric iron by Acidithiobacillus ferrooxidans and its relevance to acid mine drainage. Appl Environ Microbiol 69, 6165-6173.

Egal, M., Casiot, C., Morin, G., Parmentier, M., Bruneel, O., Lebrun, S. \& Elbaz-Poulichet, F. (2009). Kinetic control on the formation of tooeleite, schwertmannite and jarosite by Acidithiobacillus ferrooxidans strains in an As(III)-rich acid mine water. Chem Geol 265, 432441.

Fukumori, Y., Yano, T., Sato, A. \& Yamanaka, T. (1988). Fe(II) oxidizing enzyme purified from Thiobacillus ferrooxidans. FEMS Microbiol Lett 50, 169-172.

Guo, Y., Zheng, W., Rong, X. \& Huang, Y. (2008). A multilocus phylogeny of the Streptomyces griseus $16 \mathrm{~S}$ rRNA gene clade: use of multilocus sequence analysis for streptomycete systematics. Int J Syst Evol Microbiol 58, 149-159.

Hallberg, K. B., Coupland, K., Kimura, S. \& Johnson, D. B. (2006). Macroscopic streamer growths in acidic, metal-rich mine waters in north Wales consist of novel and remarkably simple bacterial communities. Appl Environ Microbiol 72, 2022-2030.

Hallberg, K. B., Amouric, A., Brochier-Armanet, C., Bonnefoy, V. \& Johnson, D. B. (2009). Physiological and phylogenetic heterogeneity among iron-oxidizing Acidithiobacillus spp., and characteristics of the novel species Acidithiobacillus ferrivorans. Adv Mat Res 71-73, 167170.

Hallberg, K. B., Gonzalez-Toril, E. \& Johnson, D. B. (2010). Acidithiobacillus ferrivorans, sp. nov.; facultatively anaerobic, psychrotolerant iron-, and sulfur-oxidizing acidophiles isolated from metal mine-impacted environments. Extremophiles 14, 9-19.

Harneit, K., Göksel, A., Kock, D., Klock, J.-H., Gehrke, T. \& Sand, W. (2006). Adhesion to metal sulfide surfaces by cells of Acidithiobacillus ferrooxidans, Acidithiobacillus thiooxidans and Leptospirillum ferrooxidans. Hydrometallurgy 83, 245-254.

Harrison, A. P., Jr (1982). Genomic and physiological diversity amongst strains of Thiobacillus ferrooxidans, and genomic comparison with Thiobacillus thiooxidans. Arch Microbiol 131, 68-76.

Harrison, A. P., Jr (1984). The acidophilic thiobacilli and other acidophilic bacteria that share their habitat. Annu Rev Microbiol 38, 265-292.

Hippe, H. (2000). Leptospirillum gen. nov. (ex Markosyan 1972), nom. rev., including Leptospirillum ferrooxidans sp. nov. (ex Markosyan 1972), nom. rev. and Leptospirillum thermoferrooxidans sp. nov. (Golovacheva et al. 1992). Int J Syst Evol Microbiol 50, 501-503.

Holmes, D. \& Bonnefoy, V. (2007). Genetic and bioinformatic insights into iron and sulfur oxidation mechanisms of bioleaching organisms. In Biomining, pp. 281-307. Edited by D. E. Rawlings \& D. B. Johnson. Berlin, Heidelberg: Springer-Verlag. 
Holmes, D. E., Nevin, K. P. \& Lovley, D. R. (2004). Comparison of $16 \mathrm{~S}$ rRNA, nifD, recA, gyrB, rpoB and fusA genes within the family Geobacteraceae fam. nov. Int J Syst Evol Microbiol 54, 1591-1599.

Huß, V. A. R., Festl, H. \& Schleifer, K. H. (1983). Studies on the spectrophotometric determination of DNA hybridization from renaturation rates. Syst Appl Microbiol 4, 184-192.

Ida, C., Sasaki, K., Ando, K., Blake, R. C., II, Saiki, H. \& Ohmura, N. (2003). Kinetic rate constant for electron transfer between ferrous ions and novel rusticyanin isoform in Acidithiobacillus ferrooxidans. J Biosci Bioeng 95, 534-537.

Jobb, G., von Haeseler, A. \& Strimmer, K. (2004). TREEFINDER: a powerful graphical analysis environment for molecular phylogenetics. BMC Evol Biol 4, 18.

Johnson, D. B. \& Hallberg, K. B. (2007). Techniques for detecting and identifying acidophilic mineral-oxidizing microorganisms. In Biomining, pp. 237-261. Edited by D. E. Rawlings \& D. B. Johnson. Berlin: Springer-Verlag.

Karavaiko, G. I., Turova, T. P., Kondrat'eva, T. F., Lysenko, A. M., Kolganova, T. V., Ageeva, S. N., Muntyan, L. N. \& Pivovarova, T. A. (2003). Phylogenetic heterogeneity of the species Acidithiobacillus ferrooxidans. Int J Syst Evol Microbiol 53, 113-119.

Kelly, D. P. \& Wood, A. P. (2005). Genus Acidithiobacillus. In Bergey's Manual of Systematic Bacteriology, pp. 60-62. Edited by D. J. Brenner, N. R. Krieg \& J. T. Staley. Michigan: Bergey's Manual Trust.

Kupka, D., Rzhepishevska, O. I., Dopson, M., Lindstrom, E. B., Karnachuk, O. V. \& Tuovinen, O. H. (2007). Bacterial oxidation of ferrous iron at low temperatures. Biotechnol Bioeng 97, 1470-1478.

Kusano, T., Takeshima, T., Sugawara, K., Inoue, C., Shiratori, T., Yano, T., Fukumori, Y. \& Yamanaka, T. (1992). Molecular cloning of the gene encoding Thiobacillus ferrooxidans Fe(II) oxidase. High homology of the gene product with HiPIP. J Biol Chem 267, 1124211247.

Larkin, M. A., Blackshields, G., Brown, N. P., Chenna, R., McGettigan, P. A., McWilliam, H., Valentin, F., Wallace, I. M., Wilm, A. \& other authors (2007). CLUSTAL W and CLUSTAL_X version 2.0. Bioinformatics 23, 2947-2948.

Leathen, W. W. \& Braley, S. A. (1954). A new iron-oxidizing bacterium: Ferrobacillus ferrooxidans. Bacteriol Proc 1954, 44.

Li, Y. Q., Wan, D. S., Huang, S. S., Leng, F. F., Yan, L., Ni, Y. Q. \& Li, H. Y. (2010). Type IV pili of Acidithiobacillus ferrooxidans are necessary for sliding, twitching motility, and adherence. Curr Microbiol 60, 1724.

Liu, Z., Guiliani, N., Appia-Ayme, C., Borne, F., Ratouchniak, J. \& Bonnefoy, V. (2000). Construction and characterization of a $r e c A$ mutant of Thiobacillus ferrooxidans by marker exchange mutagenesis. J Bacteriol 182, 2269-2276.

Luo, H., Shen, L., Yin, H., Li, Q., Chen, Q., Luo, Y., Liao, L., Qiu, G. \& Liu, X. (2009). Comparative genomic analysis of Acidithiobacillus ferrooxidans strains using the A. ferrooxidans ATCC 23270 wholegenome oligonucleotide microarray. Can J Microbiol 55, 587-598.

Maiden, M. C. (2006). Multilocus sequence typing of bacteria. Annu Rev Microbiol 60, 561-588.

Mitchell, D., Harneit, K., Meyer, G., Sand, W. \& Stackebrandt, E. (2003). Systematic analysis of our culture collection for "genospecies" of Acidithiobacillus ferrooxidans, Acidithiobacillus thiooxidans and Leptospirillum ferrooxidans. In International Biohydrometallurgy Symposium, Athens, Greece.

Ni, Y. Q., Yang, Y., Bao, J. T., He, K. Y. \& Li, H. Y. (2007). Inter- and intraspecific genomic variability of the $16 \mathrm{~S}-23 \mathrm{~S}$ intergenic spacer regions (ISR) in representatives of Acidithiobacillus thiooxidans and Acidithiobacillus ferrooxidans. FEMS Microbiol Lett 270, 58-66.
Ni, Y., Wan, D. \& He, K. (2008a). $16 \mathrm{~S}$ rDNA and 16S-23S internal transcribed spacer sequence analyses reveal inter- and intraspecific Acidithiobacillus phylogeny. Microbiology 154, 2397-2407.

Ni, Y. Q., He, K. Y., Bao, J. T., Yang, Y., Wan, D. S. \& Li, H. Y. (2008b). Genomic and phenotypic heterogeneity of Acidithiobacillus spp. strains isolated from diverse habitats in China. FEMS Microbiol Ecol 64, 248-259.

Novo, M. T. M., De Souza, A. P., Garcia Junior, O. \& Ottoboni, L. M. (1996). RAPD genomic fingerprinting differentiates Thiobacillus ferrooxidans strains. Syst Appl Microbiol 19, 91-95.

Okibe, N., Gericke, M., Hallberg, K. B. \& Johnson, D. B. (2003). Enumeration and characterization of acidophilic microorganisms isolated from a pilot plant stirred-tank bioleaching operation. Appl Environ Microbiol 69, 1936-1943.

Paulino, L. C., Bergamo, R. F., Garcia, O., Jr, de Mello, M. P., Manfio, G. P. \& Ottoboni, L. M. (2001). Molecular characterization of Acidithiobacillus ferrooxidans and A. thiooxidans strains isolated from mine wastes in Brazil. Antonie van Leeuwenhoek 80, 65-75.

Peng, H., Yang, Y., Li, X., Qiu, G., Liu, X., Huang, J. \& Hu, Y. (2006). Structure analysis of $16 \mathrm{~S}$ rDNA sequences from strains of Acidithiobacillus ferrooxidans. J Biochem Mol Biol 39, 178-182.

Philippe, H. (1993). MUST, a computer package of Management Utilities for Sequences and Trees. Nucleic Acids Res 21, 5264-5272.

Quatrini, R., Appia-Ayme, C., Denis, Y., Ratouchniak, J., Veloso, F., Valdes, J., Lefimil, C., Silver, S., Roberto, F. \& other authors (2006). Insights into the iron and sulfur energetic metabolism of Acidithiobacillus ferrooxidans by microarray transcriptome profiling. Hydrometallurgy 83, 263-272.

Quatrini, R., Appia-Ayme, C., Denis, Y., Jedlicki, E., Holmes, D. S. \& Bonnefoy, V. (2009). Extending the models for iron and sulfur oxidation in the extreme acidophile Acidithiobacillus ferrooxidans. BMC Genomics 10, 394.

Razzell, W. E. \& Trusell, P. C. (1963). Isolation and properties of an iron-oxidizing Thiobacillus. J Bacteriol 85, 595-603.

Rivas, R., Martens, M., de Lajudie, P. \& Willems, A. (2009). Multilocus sequence analysis of the genus Bradyrhizobium. Syst Appl Microbiol 32, 101-110.

Ronquist, F. \& Huelsenbeck, J. P. (2003). MrBayes 3: Bayesian phylogenetic inference under mixed models. Bioinformatics 19, 15721574.

Sand, W., Rohde, K., Sobotke, B. \& Zenneck, C. (1992). Evaluation of Leptospirillum ferrooxidans for leaching. Appl Environ Microbiol 58, 85-92.

Sasaki, K., Ida, C., Ando, A., Matsumoto, N., Saiki, H. \& Ohmura, N. (2003). Respiratory isozyme, two types of rusticyanin of Acidithiobacillus ferrooxidans. Biosci Biotechnol Biochem 67, 1039-1047.

Selenska-Pobell, S., Otto, A. \& Kutschke, S. (1998). Identification and discrimination of thiobacilli using ARDREA, RAPD and repAPD. J Appl Microbiol 84, 1085-1091.

Stackebrandt, E. \& Goebel, B. M. (1994). Taxonomic note: a place for DNA-DNA reassociation and $16 \mathrm{~S}$ rRNA sequence analysis in the present species definition in bacteriology. Int J Syst Bacteriol 44, 846-849.

Suzuki, I., Takeuchi, T. L., Yuthasastrakosol, T. D. \& Oh, J. K. (1990). Ferrous iron and sulfur oxidation and ferric iron reduction activities of Thiobacillus ferrooxidans are affected by growth on ferrous iron, sulfur, or a sulfide ore. Appl Environ Microbiol 56, 1620-1626.

Takamori, T., Kakuta, H. \& Sumiya, M. (1983). Some properties of Thiobacillus ferrooxidans and applications of the properties to improvement of the rate of sulfide mineral leaching. In International Symposium on Biohydrometallurgy, pp. 679-691. Edited by G. Rossi \& A. E. Torma. Calgari, Sardinia, Italy: Associazione Mineraria Sarda: Iglesias, Italy. 
Tomizuka, N., Yagisawa, M., Someya, J. \& Takahara, Y. (1976). Continuous leaching of uranium by Thiobacillus ferrooxidans. Agric Biol Chem 40, 1019-1025.

Valdés, J., Pedroso, I., Quatrini, R., Dodson, R. J., Tettelin, H., Blake, R., II, Eisen, J. A. \& Holmes, D. S. (2008). Acidithiobacillus ferrooxidans metabolism: from genome sequence to industrial applications. $B M C$ Genomics 9, 597.

Wakai, S., Kikumoto, M., Kanao, T. \& Kamimura, K. (2004). Involvement of sulfide: quinone oxidoreductase in sulfur oxidation of an acidophilic iron-oxidizing bacterium, Acidithiobacillus ferrooxidans NASF-1. Biosci Biotechnol Biochem 68, 2519-2528.

Wakao, N., Hanada, K., Takahashi, A., Sakurai, Y. \& Shiota, H. (1991). Morphological, physiological, and chemotaxonomical characteristics of iron- and sulfur-oxidizing bacteria isolated from acid mine drainage waters. J Gen Appl Microbiol 37, 35-48.

Wakeman, K., Auvinen, H. \& Johnson, D. B. (2008). Microbiological and geochemical dynamics in simulated-heap leaching of a polymetallic sulfide ore. Biotechnol Bioeng 101, 739-750.

Waltenbury, D. R., Leduc, L. G. \& Ferroni, G. D. (2005). The use of RAPD genomic fingerprinting to study relatedness in strains of Acidithiobacillus ferrooxidans. J Microbiol Methods 62, 103-112.
Wayne, L. G., Brenner, D. J., Colwell, R. R., Grimont, P. A. D., Kandler, O., Krichevsky, M. I., Moore, L. H., Moore, W. E. C., Murray, R. G. E. \& other authors (1987). International Committee on Systematic Bacteriology. Report of the ad hoc committee on reconciliation of approaches to bacterial systematics. Int J Syst Bacteriol 37, 463-464.

Williams, K. P., Gillespie, J. J., Sobral, B. W., Nordberg, E. K., Snyder, E. E., Shallom, J. M. \& Dickerman, A. W. (2010). Phylogeny of gammaproteobacteria. J Bacteriol 192, 2305-2314.

Yarzábal, A., Duquesne, K. \& Bonnefoy, V. (2003). Rusticyanin gene expression of Acidithiobacillus ferrooxidans ATCC 33020 in sulfurand in ferrous iron-media. Hydrometallurgy 71, 107-114.

Yarzábal, A., Appia-Ayme, C., Ratouchniak, J. \& Bonnefoy, V. (2004). Regulation of the expression of the Acidithiobacillus ferrooxidans rus operon encoding two cytochromes $c$, a cytochrome oxidase and rusticyanin. Microbiology 150, 2113-2123.

Young, J. M., Park, D. C., Shearman, H. M. \& Fargier, E. (2008). A multilocus sequence analysis of the genus Xanthomonas. Syst Appl Microbiol 31, 366-377.

Edited by: W. Liesack 